\title{
Ten Commandments for Academics Who Want to Influence Congress
}

Speaking at an invited session on "Funding for Physics Research for the 1990s" at the American Physical Society Meeting, March 21-25, 1988 in New Orleans, Louisiana, Harold Hanson listed the following "Ten Commandments for Academics Who
Want to Influence Congress." Hanson is executive director of the House Science, Space and Technology Committee. (See the May 1988 issue of the MRS BULLETIN, p. 41-42, for a report on the APS Meeting and the session on physics funding.)
L. Thou Shalt Know Thy Congressman Get to know the Congressman of Senator from your district or state on a personal basis. Get close enough to him that he knows your name and who you are, and what organization, lab, or school you are with. For the most part that will be easier than you think.

\section{Thou Shalt Know About Thy Congressuan}

Get to know about him so that you don't commit any faux pas that will damage your basic cause. For example, don't rail against pork-barrel politics when you are there trying to bring home a little bacon of your own. It is not likely that the Congressman will share all your political views, and his general voting record might be other than you would like. However, the only voting record that counts, at the time, is the one he will make on the issue you are pressing.

III. Thou Shalt Not Limit Visitatlons to Crisis Situations Make sure that some of the visits are just attitude-enhancing efforts. Visit often for a "hi" and a handshake. The influence you have will fall off inversely as some high power of the length of time between visits.

\section{Thou Shait Know the Congressman's Staff People} The Congressman is the one who gets elected and reelected on the basis of how well he represents his constituency on the various issues with which he is confronted. Nevertheless, all Congressmen need help in dealing with the vast plethora of problems. It is the Congressman's staff that supply that help. Educating the staff may be as significant as educating the Congressman-and staffers can usually give you more time than the Congressman can.

\section{Thou Shalt Have a Focused and Conclse Message} The Congressman has even less disposable time than you do, so don't overburden him with detail and don't protract the session. There may be no points to be gained by finishing on schedule, but there are definitely points to be lost by not finishing in the time you've been allotted. Some of the detail, so near and dear to you, can possibly be shared with the staff.
V. Thou Shalt Not Commit Effrontery Toward Someone Else's Project

Be positive about your own shtick, and do not attack another program gratuitously. Congressmen will have to make choices, but they don't appreciate academic intellectuals telling them what an easy and obvious choice it is, especially if you urge them to scuttle programs to which they are committed.

VII. Thou Shalt Vislt the Congressman In His District When he's not in Washington politicking, he's in his district politicking, and there are ways of showing him at home that there are real votes involved. Also consider volun. teering a few hours of your time (or a relative's time) for envelope-stuffing and making phone calls.

\section{Thou Shalt Get to Know Who the Key} Congressmen Are

Know who they are in terms of major committee assignments, and make informed liaisons with other scientists who are in the districts served by these key Congressmen.

\section{Thou Shalt Accept a Turn-Down or Set-Back Graclously Recognize that when the Congressman votes contrary to your urging, it won't be because he is ignorant or unin- formed. Perhaps his philosophical priorities are different than yours, and, of course, it may be that political consid- erations dictate a certain vote. That is not always easy for dedicated academics to accept, but it is wisest that you do so. And then keep trying, in a pleasant fashion, to get him to vote the way you are convinced is right.}

X. Thou Shait Not Do Thy Lobbying Like a Lobbylst Your competitors for the Congressman's attention and vote are professionals with beaucoup bucks at their disposal. Therefore you should forget about inviting him to lunch $\rightarrow$ or any other blandishments. He has many more invitations than he can accept and he has very little time. Just know your facts and be prepared to answer tough questions sometimes innocuously put. Be as straight as you know how to be in making your case, and don't underestimate what the Congressman may already know about your problem.

House Science, Space and Technology Committee 